\title{
Selecting The Best Supplier in Procurement Section (Goods Spot Purchase) - Departement SCM With Analytical Hierarchy Process (AHP) Method
}

\author{
Marline Louister Siregar and Suparno \\ Department of Systems Engineering and Industry, Institut Teknologi Sepuluh Nopember, Surabaya \\ e-mail: suparno@ie.its.ac.id
}

\begin{abstract}
Choosing suppliers is one of the upstream supply chain areas that affect the quality of the products produced by a company. This study aims to develop a framework for selecting the best suppliers/suppliers in the Procurement Section (Goods Spot Purchase), the SCM Department at the company. According to the AHP method, this study will determine the main criteria through interviews, questionnaires, and pair-wise comparison in developing AHP, and determine the sub-criteria based on the main criteria. The result is forming the best supplier selection framework based on the requirements set by the company. Also, the main criteria for selecting the best suppliers are price, quality, delivery. flexibility and response, and Vendor Performance. This study might be beneficial to be implemented in the company, in terms of the best supplier selection in the Non-stock purchase section of the Procurement Section, the SCM Department objectively.
\end{abstract}

Keywords-Analytical Hierarchy Process, Best Supplier Selection Criteria, Determination of the main criteria, Determination of sub-criteria, Supplier / Supplier.

\section{I.INTRODUCTION}

A $\mathrm{T}$ present, the supply chain is a complex network consisting of all stages, for example, ordering, purchasing, inventory control, manufacturing and, distribution, which are involved starting from the production process to delivering the final product/service to consumers. Ting, S.C., and D.I. Cho [1] states that the entire chain connects customers, manufacturers, and suppliers, which starts with the creation of raw materials or components by the supplier and ends with the consumption of the product by the customer. Amiri [2] states that supplier selection is one of the critical activities in purchasing management in the supply chain because supplier performance plays an important role in cost, quality, delivery, and services in achieving the objectives of a supply chain. According to Blocher [3], so far the purchasing managers of an industrial company more often use the lowest price quote factor to choose suppliers among suppliers. Another factor that is also dominantly used is the desire to immediately own and fulfill inventory needs (stock) of goods. Decision making in the selection of suppliers like this can be a big risk to the use of raw materials when the company will start production activities.

The selection of suppliers used is a complex activity because it involves many criteria. Dickson [4] states that there are 23 criteria in selecting suppliers. However, not all of the criteria will be used by the company. Some commonly used criteria are quality, price, quantity, accuracy, and speed of delivery. Several methods can be used in selecting suppliers. Tahriri [5] states that the main purpose of the supplier selection process is to reduce the risk of purchasing, maximize overall value for buyers, and build a close and long-term relationship between buyers and suppliers. The method for selecting suppliers must be adjusted to supplier performance criteria set by the company, supplier flexibility, and other factors.

The contemporary business environment practically shows that many organizations choose suppliers based on price criteria only. Some organizations also use other criteria depending on their policies such as quality, capacity, the reputation of the supplier. Therefore, an efficient supplier selection process must exist and is crucial for successful supply chain management. Especially if the company has many suppliers, the company has difficulty determining whether a supplier in the field of goods is indeed appropriate or suiTable to provide goods based on commodities that have been determined or not. So it is deemed necessary to make a framework/criteria for selecting suppliers that are following company criteria so that the selected suppliers will be able to carry out their obligations to provide the goods needed by the company for the production process. In practice, the use of personal judgment and criteria is still a major element in supplier selection. This shows that companies need to use objective criteria and methods in the supplier selection process. This study aims through the use of an analytical Hierarchy Process (AHP) to build a model that uses objective criteria in supplier selection so that it is expected to obtain the most important criteria that can be used as benchmarks in supplier selection, to be aligned with company strategy.

There are many papers discussing supplier selection methods using AHP. Yousef A. Abu Hajar [6] used the AHP to build a supplier selection model, utilizing the competitive priority "quality, cost, delivery, and flexibility" as evaluation and selection criteria. Franklin Liu \& Hui Lin Hai [7] presented a new weighting procedure replacing AHP pairwise comparisons to select suppliers. Al-Rafati [8] used the AHP to determine the main criteria for photocopy suppliers in the Palestinian finance ministry. Tahriri [5] uses AHP to determine the criteria for the best suppliers in the steel industry. Rohaizan Ramlan and Lee Wen Qiang [9] conducted an AHP-based supplier selection model that was applied to improve and assist decision making to solve the problem of supplier selection in choosing the optimal supplier combination. 


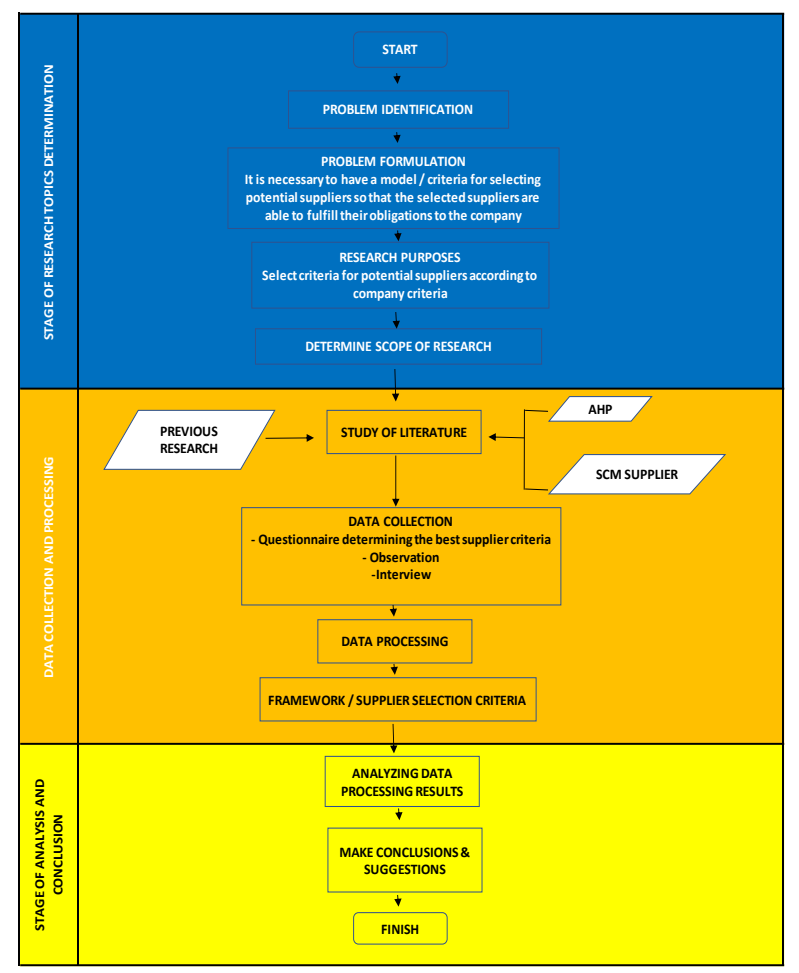

Figure 1. Research Methodology for this research.

Table 1.

The proposed Criteria \& Sub criteria of the researcher, which were used in this study

\begin{tabular}{|c|c|}
\hline Criteria & Sub Criteria \\
\hline (Price) & $\begin{array}{l}\text { Competitive price, Discount, Price consistency, } \\
\text { Supplier Term of Payment }\end{array}$ \\
\hline (Quality) & $\begin{array}{l}\text { As per desired specifications, Warranty, } \\
\text { Product Endurance, Refers to the expertise \& } \\
\text { ability of suppliers to the goods supplied }\end{array}$ \\
\hline (Delivery) & $\begin{array}{l}\text { Goods received in good condition, Accuracy in } \\
\text { the number of goods shipped, Accuracy in the } \\
\text { specifications of goods sent, On-time delivery }\end{array}$ \\
\hline $\begin{array}{l}\text { (Flexibility \& } \\
\text { Respond) }\end{array}$ & $\begin{array}{l}\text { Response to demand goods, Response to } \\
\text { complaints/claims, Flexibility to change } \\
\text { demand }\end{array}$ \\
\hline $\begin{array}{l}\text { Vendor } \\
\text { Performance }\end{array}$ & $\begin{array}{l}\text { Refers to relatively long interactions with } \\
\text { suppliers/experience, Performance Vendor } \\
\text { Index, Area Category Index }\end{array}$ \\
\hline
\end{tabular}

\section{LITERATURE REVIEW}

\section{A. Supplier Selection and Evaluation}

Supplier is a party appointed by the company and/or on its own accord to sell goods or services. Management of suppliers requires special negotiations because they are not part of the organization, so good relationships with suppliers are needed.

Supplier selection aims to get a source of material with the desired quality, quantity, time, price, and service as well as the technical assistance needed. Dobler [10] states that supplier selection is one of the important factors in the supply chain because it is one of the company's strategies to compete with other companies in terms of customer satisfaction and also to improve or maintain the company's service level in meeting consumer demand. The selection of competent suppliers is the first strategic decision that determines the
Table 2 .

Weight and ranking of each main criteria

\begin{tabular}{lcc}
\hline \hline \multicolumn{1}{c}{ Main Criteria } & Weighted & Ranking \\
\hline Price & 0.302 & 2 \\
Quality & 0.315 & 1 \\
Delivery & 0.178 & 3 \\
Flexibility \& Respond & 0.096 & 5 \\
Vendor Performance & 0.109 & 4 \\
\hline \hline
\end{tabular}

Table 3 .

Weight and ranking for sub-criteria Price

\begin{tabular}{lll}
\hline \hline Sub Criteria: Price & Weighted & Ranking \\
\hline Competitive price & 0.111 & 1 \\
Discount & 0.054 & 2 \\
Price consistency & 0.039 & 5 \\
Supplier Term of Payment & 0.053 & 3 \\
Compliance with Local Community & 0.045 & 4 \\
Development & & \\
\hline \hline
\end{tabular}

Table 4

Weight and ranking for sub-criteria Quality

\begin{tabular}{lcc}
\hline Sub criteria: Quality & Weighted & Ranking \\
\hline As per desired specifications & 0.058 & 1 \\
Warranty & 0.034 & 5 \\
Product Endurance & 0.043 & 2 \\
Refers to the expertise \& ability of & 0.027 & 7 \\
suppliers to the goods supplied & & \\
Guaranteed supply continuity & 0.037 & 4 \\
OEM, to differentiate with KW product & 0.040 & 3 \\
Origin of the product & 0.022 & 9 \\
Up to date products & 0.026 & 8 \\
Easy to upgrade product & 0.028 & 6 \\
\hline \hline
\end{tabular}

Table 5 .

Weight and ranking for sub-criteria Delivery

\begin{tabular}{lcc}
\hline \hline Sub Criteria: Delivery & Weighted & Ranking \\
\hline Goods received in good condition & 0.028 & 3 \\
Accuracy in the number of goods shipped & 0.027 & 4 \\
Accuracy in the specifications of goods & 0.029 & 1 \\
sent & & \\
On-time delivery & 0.029 & 2 \\
Complete delivery documents as needed & 0.023 & 5 \\
(Exim document, MSDS, handling & & \\
instructions, etc.) & & \\
Way of Packing Goods / Quality of & 0.019 & 6 \\
Packing & 0.010 & 8 \\
Courier or forwarder used & 0.013 & 7 \\
Mode of Shipment & & \\
\hline \hline
\end{tabular}

successful implementation of supply chain management. Supplier selection is recognized as one of the most important responsibilities in the procurement management function. A well-managed supplier in a supply chain will have a longterm effect on the overall competitiveness of the supply chain itself, and a profound impact on customer satisfaction. Supplier selection is a difficult decision because various criteria must be considered in the decision-making process. Problems that often occur in the supplier selection process include:

1) Lack of information about suppliers, so the company does not have a clear picture of its suppliers when it will determine the selected suppliers. Often the selection of suppliers is very subjective.

2) The many criteria that must be considered in choosing a supplier. Some of these criteria cannot be quantified, which causes difficulties when making decisions. 


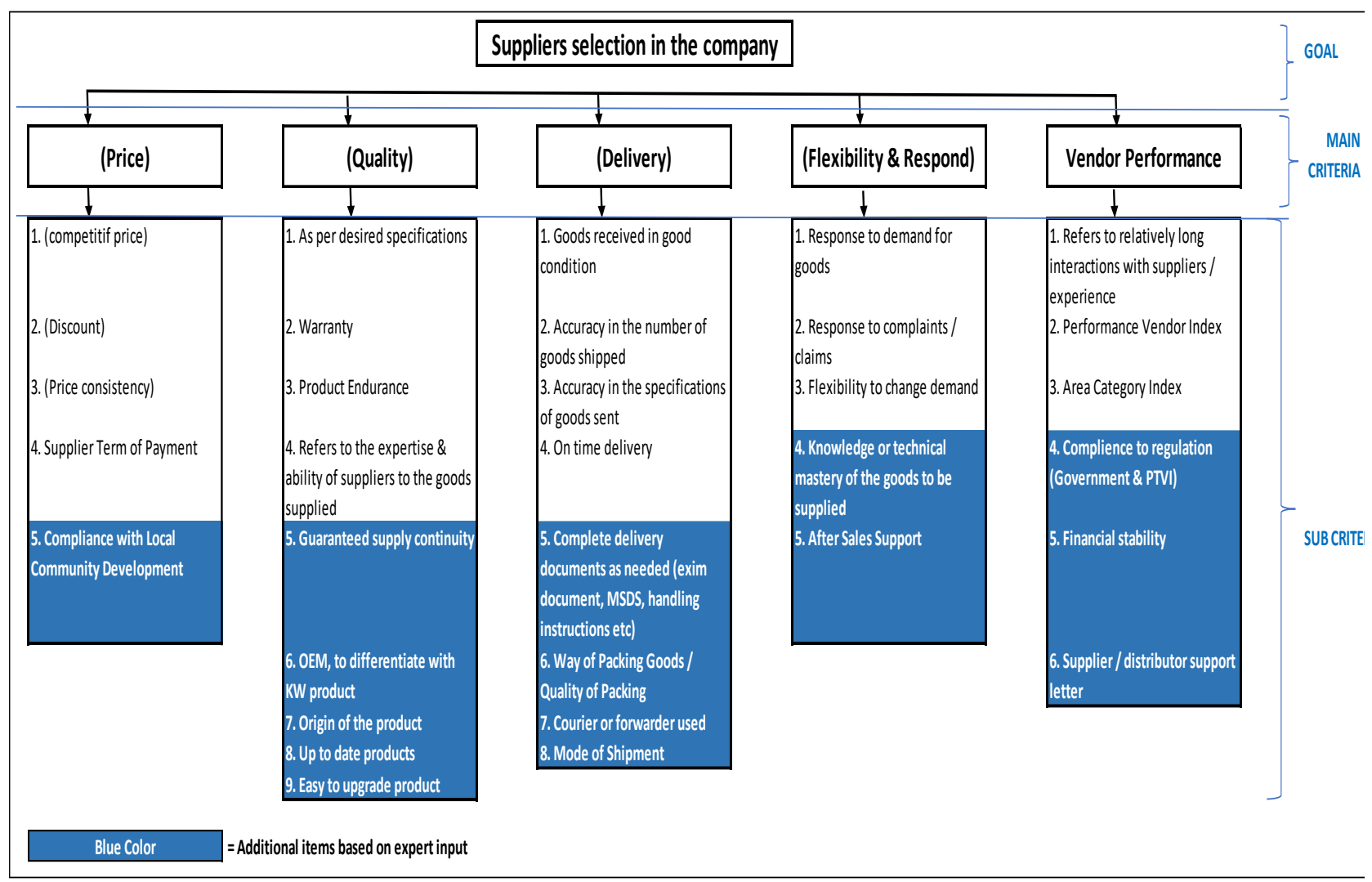

Figure 2. The criteria and sub-criteria proposed by the researcher and additional sub-criteria from experts/respondents.

\section{B. Analytical Hierarchy Process (AHP)}

Analytical Hierarchy Process (AHP) is an integrated decision-making procedure proposed by Dr. Thomas Saaty, who was a professor at the University of Pittsburgh in 1977. In 1980 and 2001, Dr. Saaty continued to improve this technique until the AHP became multiple criteria for multiple decision-making theory cooked. The main features of AHP can include analyzing complex decisions by considering a large number of factors and criteria. Tzeng \& Huang [11] mentioned that the AHP breaks down the problem into a simpler hierarchy of sub-problems, and after that, conducts a comprehensive and independent evaluation. Finally, make a decision based on the above analysis.

Data processing techniques performed using the AHP method. This method can determine the criteria and weight of each variable obtained from questionnaire data collection, interviews, and observations. The weight can then be used to find out the most important criteria that can be used as a benchmark in selecting the best supplier at the company.

Data processing techniques used to find out the most important criteria in selecting suppliers, using the AHP method are as follows:

1. Determine the geometric mean, with the formulation:

$M G=\sqrt[n]{\sum_{i=1}^{n} x_{i}}$

Where:

$\mathrm{MG}=$ geometric mean

$x_{i}=\mathrm{i}$ alternative

$\mathrm{n}=$ amount of data
2. Normalizing the process by making mean geometric proportions, with the formulation:

$P_{i}=\frac{M G i}{\sum_{i=1}^{n} M G i}$

Where:

$\mathrm{Pi}=\mathrm{i}$ alternative proportion

$\mathrm{MGi}=$ geometric mean data $\mathrm{i}$

$\mathrm{n}=$ amount of data

3. Determine the weighting of the values of each alternative to the criteria, with the formulation:

$V i=\sum_{i=1}^{n} \mathrm{P} i \mathrm{x} \mathrm{W} i$

Where:

$\mathrm{Pi}=\mathrm{i}$ alternative proportion

$\mathrm{Vi}=$ weight alternative value $\mathrm{i}$

$\mathrm{Wi}=\mathrm{i}$ criteria weight

4. Calculating the consistency of assessment, with the formulation:

$C I=\frac{\lambda \max ^{(n-1)}}{n}$

Where:

$\mathrm{CI}=$ Consistency Index

$\lambda \max =$ maximum eigen value

$\mathrm{n}=$ matrix size

$C R=\frac{C I}{R I}$

Where:

$\mathrm{CI}=$ Consistency Index

$\mathrm{CR}=$ Consistency Ratio

$\mathrm{RI}=$ Index Ratio 
The $6^{\text {th }}$ International Seminar on Science and Technology (ISST) 2020

July $25^{\text {th }}, 2020$, Institut Teknologi Sepuluh Nopember, Surabaya, Indonesia

Table 6.

Weight and ranking for sub-criteria Flexibility \& Respond

\begin{tabular}{lcc}
\hline \hline Sub criteria: Flexibility \& Respond & Weighted & Ranking \\
\hline Response to demand goods & 0.022 & 1 \\
Response to complaints / claims & 0.022 & 2 \\
Flexibility to change demand & 0.021 & 3 \\
Knowledge of technical mastery of the & 0.016 & 4 \\
goods to be supplied & & \\
After-sales Support & 0.016 & 5 \\
\hline \hline
\end{tabular}

Table 7.

Weight and ranking for sub-criteria Vendor Performance

\begin{tabular}{lcc}
\hline \hline Sub criteria: Vendor Performance & Weighted & Ranking \\
\hline Refers to relatively long interactions & 0.010 & 6 \\
with suppliers/experience & & \\
Performance Vendor Index & 0.026 & 1 \\
Area Category Index & 0.014 & 5 \\
Compliance to regulation (Government & 0.026 & 2 \\
\& PTVI) & & \\
Financial stability & 0.014 & 4 \\
Supplier / distributor support letter & 0.019 & 3
\end{tabular}

5. Determine the order of the criteria for the calculation of pairwise comparison based on the largest value.

\section{RESEARCH METHODOLOGY}

The implementation of this research follows the stages as shown in Figure 1.

\section{ANALYSIS OF RESULTS AND DISCUSSION}

To identify the main criteria and sub-criteria for supplier selection, researchers conducted interviews with several people who were considered by researchers to be experts in the procurement section. They consist of General Procurement Manager and all procurement managers. There are several main criteria and sub-criteria for selecting the best supplier proposed by the researcher. Table 1 shows the proposed criteria \& sub-criteria of the researcher, which were used in this study. Then this proposal is used as a reference during the interview with respondents.

But during the interview, there was input from the managers, so there were several criteria/sub-criteria added. Shapiro [12] states that the criteria for supplier selection or supplier performance evaluation reflect the condition of the company, not only following the theory. In Figure 2 we can see the criteria and sub-criteria proposed by the researcher and additional sub-criteria from experts/respondents.

From Figure 2 to 5 respondents who were processed using the AHP method, it can define weights and rankings for each of the main criteria and sub-criteria. The following results as shown in Table 2 were obtained for the main criteria.

From Table 2, it can be seen that the main criteria of Quality are the first or highest priority. This shows that the quality of goods is still more important than the price of goods. So, this quality factor will affect determining the supplier who wins a tender. The following results as shown in Table 3 were obtained for sub-criteria Price.

From Table 3, it can be seen that in the price criteria, the first or highest priority is the sub-criteria Competitive price. This shows that the company is expected to find suppliers with more competitive prices than other suppliers. So that the
Table 8 .

Summary calculation of the weights of the main criteria and subcriteria of the supplier selection

\begin{tabular}{|c|c|}
\hline Main Criteria/Sub Criteria & Weight \\
\hline Price & 0.302 \\
\hline Competitive price & 0.111 \\
\hline Discount & 0.054 \\
\hline Price consistency & 0.039 \\
\hline Supplier Term of Payment & 0.053 \\
\hline Compliance with Local Community Development & 0.045 \\
\hline Quality & 0.315 \\
\hline As per desired specifications & 0.058 \\
\hline Warranty & 0.034 \\
\hline Product Endurance & 0.043 \\
\hline $\begin{array}{l}\text { Refers to the expertise \& ability of suppliers to the } \\
\text { goods supplied }\end{array}$ & 0.027 \\
\hline Guaranteed supply continuity & 0.037 \\
\hline OEM, to differentiate with KW product & 0.040 \\
\hline Origin of the product & 0.022 \\
\hline Up to date products & 0.026 \\
\hline Easy to upgrade product & 0.028 \\
\hline Delivery & 0.178 \\
\hline Goods received in good condition & 0.028 \\
\hline Accuracy in the number of goods shipped & 0.027 \\
\hline Accuracy in the specifications of goods sent & 0.029 \\
\hline On-time delivery & 0.029 \\
\hline $\begin{array}{l}\text { Complete delivery documents as needed (Exim } \\
\text { document, MSDS, handling instructions, etc.) }\end{array}$ & 0.023 \\
\hline Way of Packing Goods / Quality of Packing & 0.019 \\
\hline Courier or forwarder used & 0.010 \\
\hline Mode of Shipment & 0.013 \\
\hline Flexibility \& Respond & 0.096 \\
\hline Response to demand goods & 0.022 \\
\hline Response to complaints / claims & 0.022 \\
\hline Flexibility to change demand & 0.021 \\
\hline $\begin{array}{l}\text { Knowledge of technical mastery of the goods to be } \\
\text { supplied }\end{array}$ & 0.016 \\
\hline After-sales Support & 0.016 \\
\hline Vendor Performance & 0.109 \\
\hline $\begin{array}{l}\text { Refers to relatively long interactions with } \\
\text { suppliers/experience }\end{array}$ & 0.010 \\
\hline Performance Vendor Index & 0.026 \\
\hline Area Category Index & 0.014 \\
\hline Compliance to regulation (Government \& PTVI) & 0.026 \\
\hline Financial stability & 0.014 \\
\hline Supplier / distributor support letter & 0.019 \\
\hline
\end{tabular}

competitive price factor will affect in determining the supplier who wins a tender.

From Table 4 it can be seen that in the Quality criteria, the first or highest priority is the sub-criteria According to the desired specifications. This shows that the company is expected to find suppliers who offer goods following the desired specifications. So that the factors according to the desired specifications will influence in determining the supplier who wins a tender.

The following results as shown in Table 5 were obtained for sub-criteria Delivery. From Table 5 it can be seen that in the Delivery criteria, the first or highest priority is sub-criteria the Accuracy in the number of goods shipped. This shows that the company expects to find a supplier who can deliver goods following the desired amount. So, the Accuracy factor in the number of goods shipped will affect in determining the supplier that wins a tender.

The following results as shown in Table 6 were obtained for sub-criteria Flexibility \& Respond. From Table 6 it can be seen that in the Flexibility \& Respond criteria, the first or 
The $6^{\text {th }}$ International Seminar on Science and Technology (ISST) 2020

July $25^{\text {th }}, 2020$, Institut Teknologi Sepuluh Nopember, Surabaya, Indonesia

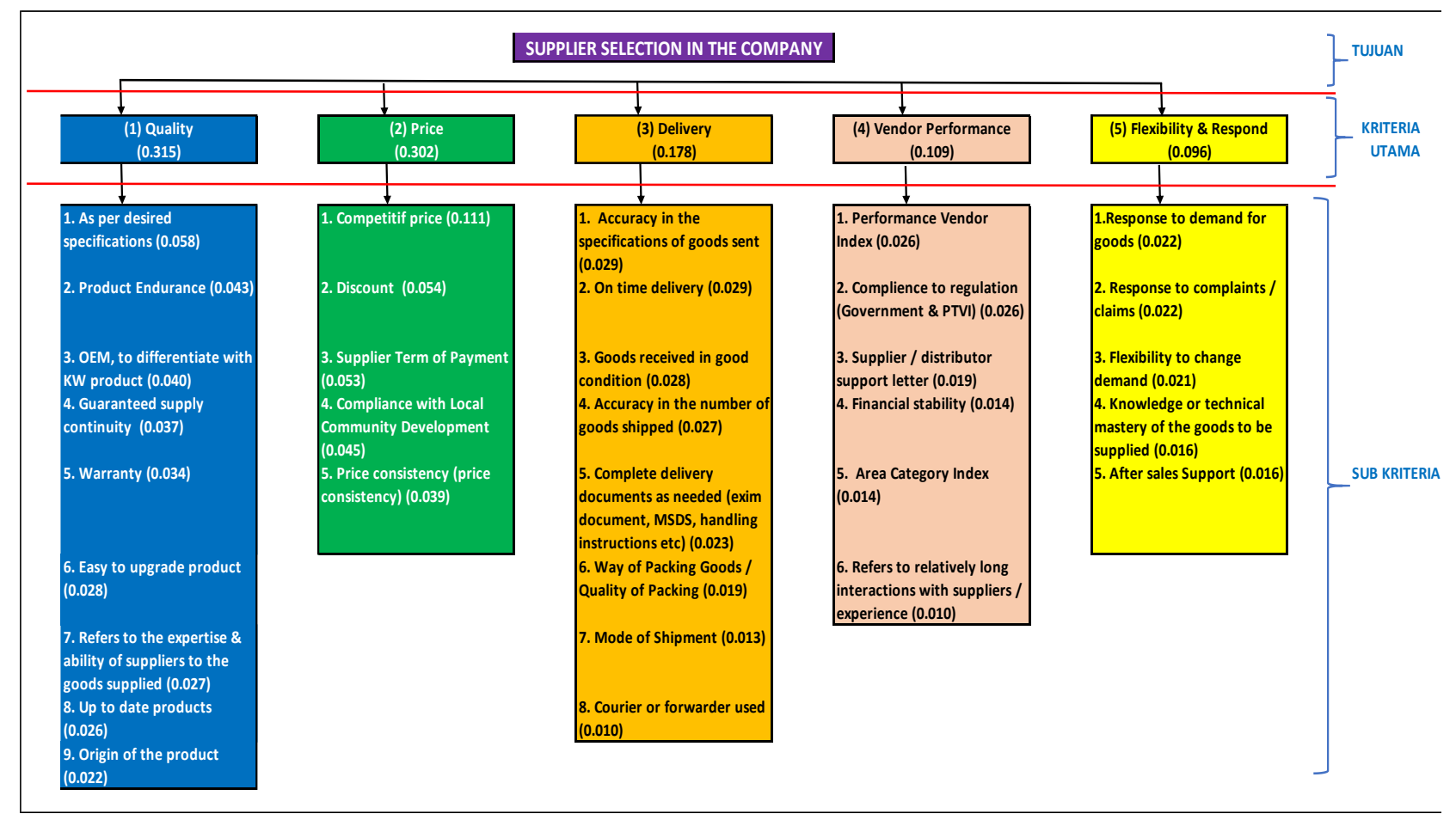

Figure 3. Summary of the weights of the main criteria and sub-criteria of the supplier selection.

highest priority sub-criteria is the Response to demand goods. This shows that the company expects to find suppliers who are quick and agile in responding to demand goods so that the production process can run smoothly. So that the Response to demand goods factor will influence in determining the supplier who wins a tender.

The following results as shown in Table 7 were obtained for sub-criteria Vendor Performance. From Table 7 it can be seen that in the Vendor Performance criteria, the first or highest priority sub-criteria is the Performance Vendor Index. This shows that companies need suppliers that have a highperformance index. Thus, it is necessary to regularly monitor the performance of each supplier. So, the Performance Vendor Index factor will influence in determining the suppliers who win a tender. Summary calculation of the weights of the main criteria and sub-criteria of the supplier selection are as Table 8 .

\section{CONCLUSION}

Based on the results of research using the AHP method, it was concluded that the most important priority for supplier selection criteria is quality. While the second criteria are the price. Delivery criteria are the third priority, while the fourth priority is the vendor performance criteria. Next, the last priority is the flexibility and response criteria. That can be seen at Figure 3.

Therefore, companies in determining their suppliers especially must look at the quality of goods purchased and sent. After that, then consider the price, delivery, vendor performance, and flexibility \& response from suppliers.

\section{REFERENCES}

[1] Ting, S.C., and D.I. Cho, An Integrated approach for supplier selection and purchasing decisions, Supply Chain Manage.; Int. J., 13: 116 127,2008

[2] Amiri RH, Jafari M, Bourouni A., A New Framework for Selection of the Best Performance Appraisal Method. European Journal of Social Sciences 7 (3): 92-100, 2009,

[3] Blocher, E.J., Kung H. Chen, Thomas.W Lin. (2002). Edisi 2., Cost Management: a strategic emphasis. Boston: McGraw Hill, Inc.

[4] Dickson, G.W., 1966, An analysis of vendor selection systems and decisions, Journal of Purchasing

[5] Tahriri F., M. R. Osman, A. Ali, R. M. Yusuff, A. Esfandiary, 2008, "AHP approach for supplier evaluation and selection in a steel manufacturing company", Journal of Industrial Engineering and Management, Vol. 1, No. 2, pp $54-76$

[6] Yousef A. Abu Hajar, Using Analytical Hierarchy Process (AHP) to Build Suppliers' Selection Model, International Journal of Academic Research in Business and Social Sciences, 2016, Vol. 6, No. 12 ISSN: 2222-6990

[7] Fuh-Hwa Franklin Liu, Hui Lin Hai, the voting analytic hierarchy process method for selecting supplier, Int. J. Production Economics 97 (2005), pp 308-317

[8] Maher H. Al-Rafati, The Use of Analytic Hierarchy Process in Supplier Selection: Vendors of Photocopying Machines to Palestinian Ministry of Finance as a Case Study, The Islamic University-Gaza, 2008

[9] Rohaizan Ramlan and Lee Wen Qiang, AN ANALYTIC HIERARCHY PROCESS APPROACH FOR SUPPLIER SELECTION: A CASE STUDY, 3rd International Conference on Global Optimization and Its Application (ICoGOIA 2014), September 9-12, 2014, Gallery Prawirotaman Hotel, Yogyakarta, Indonesia

[10] Dobler, D.W et. al., Purchasing and Material Management Text and Cases,5th.ed. Singapore: McGraw-Hill, Inc, 1990

[11] Tzeng, Gwo-Hshiung \& Huang, Jih-Jeng, Multiple Attribute Decision Making: Methods and Applications, CRC Press, A Chapman \& Hall Book, 2011

[12] Shapiro, The Essential Guide to Implementing Vendor Performance Metrics in your Import Supply Chain. Baltimore: Shapiro, (2014) 